\title{
Translating disaster resilience into spatial planning practice in South Africa: Challenges and champions
}

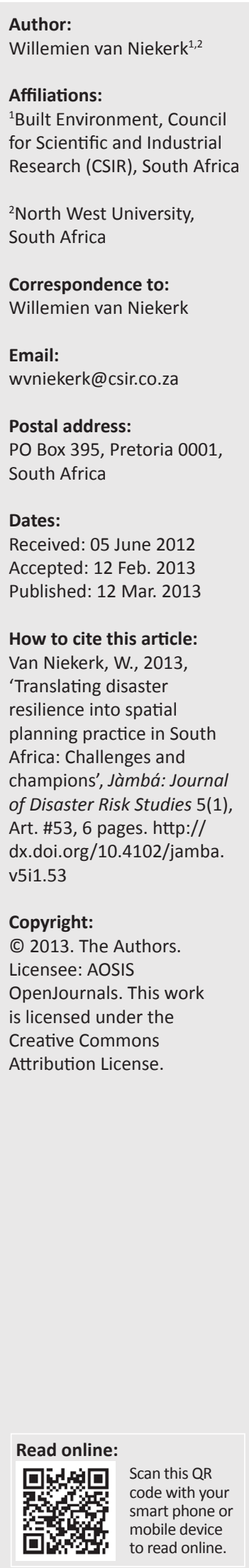

It is highly likely that hazards and extreme climatic events will occur more frequently in the future and will become more severe - increasing the vulnerability and risk of millions of poor urbanites in developing countries. Disaster resilience aims to reduce disaster losses by equipping cities to withstand, absorb, adapt to or recover from external shocks. This paper questions whether disaster resilience is likely to be taken up in spatial planning practices in South Africa, given its immediate developmental priorities and challenges. In South Africa, issues of development take precedence over issues of sustainability, environmental management and disaster reduction. This is illustrated by the priority given to 'servicing' settlements compared to the opportunities offered by 'transforming' spaces through postapartheid spatial planning. The City of Durban's quest in adapting to climate change demonstrates hypothetically that if disaster resilience were to be presented as an issue distinct from what urban planners are already doing, then planners would see it as insignificant as compared to addressing the many developmental backlogs and challenges. If, however, it is regarded as a means to secure a city's development path whilst simultaneously addressing sustainability, then disaster resilience is more likely to be translated into spatial planning practices in South Africa.

\section{Introduction}

According to the International Federation of Red Cross and Red Crescent Societies (IFRC), wellrun cities can be amongst the safest places in the world from the impact of natural hazards if basic services, food security, policing, running water and sewerage are guaranteed, and building codes are respected. However, in reality, many cities in the world are the most dangerous places on earth. 'The signs of our vulnerability to urban risk are everywhere' (IFRC 2010:8): earthquakes bringing critical urban infrastructure and assets down with tragic consequences (for example, the earthquakes in Haiti and Chile in 2010, and Japan in 2011); a volcanic eruption in one country throwing city airports across the world into chaos (for example, the volcanic eruptions in Iceland in 2010 and Chile in 2011); the drug trade turning inner cities into war zones; epidemics turning into pandemics in the developing world; and streets in the slums of developing cities turning into open sewers during seasonal flooding.

Over the past 40 years, 80000 people have been killed on average each year and 200 million people have been affected by natural disasters (UNISDR 2010b; World Bank \& United Nations 2010:23). Of greater concern than the current trends, is the increasingly clear prognosis from the United Nations International Strategy for Disaster Reduction (UNISDR) and the Intergovernmental Panel on Climate Change (IPCC) that hazards and extreme climatic events will occur more frequently in the future and will become more severe (IPCC 2007; UNISDR 2010a). Many international development organisations (IFRC 2010; IPCC 2007; UN-Habitat 2010; UNISDR 2010a; World Bank 2008) and several researchers (Wisner \& Pelling 2009; Puppim de Oliveira 2009; Pelling 2003) warn us that as urbanisation and other global processes continue, a 'strange new urban world' (IFRC 2010:8) is developing - one that is increasingly at risk of experiencing natural, social and/ or industrial disasters beyond many urban authorities' experience and ability to manage (ICLEI 2010). The consequences are bigger losses more often, but also long-term implications for human settlements - settlements, particularly in the developing world, that are already challenged by a range of socio-economic development stresses (Parnell, Simon \& Vogel 2007:359).

'An emphasis on resilience, rather than just disaster response and recovery has become a mainstream idea in disaster reduction' (Collins 2009:103). Whereas disaster reduction seeks to identify and reduce vulnerabilities and risks, resilience (defined below) is also partly defensive, but more creative in implying coping and adaptation. Planning for resilient cities thus involves more than merely being occupied with minimum standards or widely-accepted spatial designs, it involves accommodation of and adaptation to changing conditions over the long-term (Collins 2009:104). 
This article questions whether disaster resilience is likely to be translated into spatial planning practice in South Africa, given its immediate developmental priorities and challenges. The article starts by considering what risk, vulnerability and resilience mean conceptually; then discusses the planning context and spatial planning practices in post-apartheid South Africa; and concludes with a case study on the City of Durban to demonstrate how a 'new' policy paradigm has recently been mainstreamed into local planning practices, in spite of developmental and intergovernmental challenges.

\section{Conceptual framework Urban disaster risk and vulnerability}

The vulnerability of people to disasters is increasing progressively, and, if left unchecked, will augment the local disaster risk burden of the world's urban poor (Laukkonen et al. 2009). An urban risk divide is developing in cities as they become increasingly unjust, polarised, divided and fragmented: the well-connected elite barricade themselves in well-serviced and regulated high-security villages (Todes 2011:116; Watson 2005:286), whilst some communities struggle to survive along the fault lines of urban risk (IFRC 2010:8). The poor are largely 'priced out' of safe areas and are concentrated in severely vulnerable and unsafe spaces - most often in informal settlements that are low-lying or steeply-sloping, flood-prone, close to pollution sources, often at highest risk of fire and disease, cauldrons of social tension and crime, with inadequate or non-existent services, and lack of protection from extreme climatic events (Parnell et al. 2007; Pelling \& Wisner 2009). Hazards interact with each other to produce compound hybrid hazards, and as everyday disaster risk grows, it undermines the coping capacities of communities. Each succeeding event erodes the resources of a household to cope with and recover in time for the next shock, resulting in a 'ratchet effect' of vulnerability (Faling 2012; Freeman et al. 2002:5; Laukkonen et al. 2009:287; Parnell et al. 2007:357, 361; Pelling 2003:16; Pelling \& Wisner 2009:4).

It is clear that addressing urban disaster risk and vulnerability is critical in protecting the lives and livelihoods of people, as well as the infrastructure and development gain. Resilience offers a perspective on reducing disasters and everyday risks, as well as making people and places more robust and adaptable to changes and shocks.

\section{Resilient cities}

'Cities are among humankind's most durable artefacts' (Vale \& Campanella 2005a:5). Resilience is perhaps a new metaphor to many disciplines, being used to describe and frame a counter-response to threat, but resilience has always preoccupied the inhabitants of cities as they sought to defend and secure their interests. The rise of resilience is ascribed to a growth in political action against a number of perceived threats and events such as climate change-related events, disease pandemics and global terrorism (Coaffee, Wood \& Rogers 2009:1; Todes, 2011:118).
C.S. Hollings introduced the term 'resilience' for the first time in 1973 as applied to the analysis of ecosystems. It emerged as a concept in ecosystems theory to explain how ecological systems cope with external shocks, or how to interpret their stability (Coaffee 2009:85; Ernstson 2008:17). Ecological resilience was defined as the amount of disturbance that an ecosystem could withstand without changing self-organized processes and structures' (Coaffee et al. 2009:112). The range of application of the term resilience has since then broadened in both theory and research. In recent years resilience has become a transdisciplinary concept that integrates sociopolitical and physical aspects (Coaffee 2009:87) and is becoming a common frame for the policy goals of socioecological systems - such as cities (Coaffee et al. 2009:114; Hamin \& Guran 2009:239). Resilience as a concept has its critics though: it is seen by some as merely aspiring to return to the situation before the shock, with no aspirations for transforming society, and therefore only benefitting some and not those most at risk (Pelling 2011).

Resilience is popularly understood as the capacity to accommodate, absorb, bounce back from, or adapt to some kind of perturbation (Hamin \& Guran 2009:239; Vale \& Campanella 2005b:335; World Bank 2008:32). If resilient, a system has a degree of elasticity, allowing it to withstand a shock and reorganise itself when necessary (World Bank 2008:32) and is thus forgiving of external shocks (Hamin \& Guran 2009:239). Resilience is indicated by the continuation of particular functions at an acceptable level (Pelling 2011:42). Moreover, it includes the ability to learn by continuously adapting to the constantly changing risks and vulnerabilities (Collins 2009:106; Hamin \& Guran 2009:239).

The goals of a disaster-resilient city need to be built into the everyday practices of urban planning (Coaffee 2009:87). However, urban planning, particularly in the developing world, has so far played a limited role in consciously reducing vulnerability to disasters or everyday risks; and disaster resilience is little understood (Biesbroek, Swart \& Van der Knaap 2009). The International Council for Local Environmental Initiatives (ICLEI) sums up the reason for the lack of action:

' $[W]$ hile the changing nature of disaster risk is well analyzed and increasingly addressed at international and national levels of debate and decision-making, efforts to provide direct and practical guidance to local government policy-makers and planners on how to reduce exposure and increase resilience to disasters have been few'. (ICLEI 2010:1)

Because disaster resilience is not made practical, planning practices are often unsustainable - in fact, our everyday decisions could even increase people's exposure to risks and hazards, as opposed to building resilience (Pelling 2003).

Most planners would agree that building disaster-resilient cities is of great consequence, but many countries in the developing world, including South Africa, have major immediate development challenges - compared to which the pursuit of resilience seems like a 'nice to have'. The next 
section considers whether disaster resilience is likely to be translated into spatial planning practice in South Africa.

\section{Contextual framework The South African planning context}

Pre-1994, apartheid had purposefully and systematically restricted black South Africans from meaningful participation in the economy. The assets of the majority of people were directly and indirectly destroyed and access to skills and selfemployment was racially restricted (The Presidency 2009; Todes 2011). Despite solid and consistent economic growth for most of the past 18 years, and numerous policy and legislation changes, the present resilience of urban settlements in South Africa is endangered by spatial inequalities, fragmentation, urban sprawl, inequalities between rich and poor that are deepening, the overload on basic infrastructure and services, congestion on roads, social exclusion, increased crime, and pressure on ecosystem services (Biermann 2011:14). Despite having one of the largest public housing projects in the world, decent shelter near employment opportunities remains elusive for most people - many do not have access to housing or security of tenure, quality social services, public facilities and amenities, economic opportunities and livelihoods, and/or basic services. Moreover, the South African space economy is characterised by the coexistence of formal and informal economic activities, housing and transportation systems, and a dualism in quality of all aspects of life (Biermann 2011:14, 16; Oranje 2010:59; World Bank Institute 2012). The stark inequalities in the country threaten the fragile social cohesion, and have given rise to an increasing number of violent service delivery protests and xenophobic attacks. There are, furthermore, huge territorial disparities between rural and urban areas (Van Huyssteen et al. 2010:24-25, 35).

\section{Planning in South Africa}

With the rise of democracy in South Africa, expectations of the eradication of socio-economic imbalances, including equitable development and access to basic services, were high (Carmin, Anguelovski \& Roberts 2012:21). A new path of reconstruction and development was cut out for a postapartheid South Africa in the form of numerous green and white policy papers, Acts and regulations. Simultaneously, a new intergovernmental system was established with a strong focus on the process of inclusive planning rather than planning products (Biermann 2011; Oranje \& Van Huyssteen 2011:8), thus Integrated Development Plans (IDPs), which promote the developmental government paradigm (including disaster management), became the dominant planning instrument in post-apartheid South Africa. These plans focus on stakeholder processes and institutional coordination but neglect the notion of using space to restructure settlements. Watson calls this preoccupation with intergovernmental coordination at the expense of transforming previously disadvantaged settlements the 'marginalization of the spatial' (in Biermann 2011:12).
Oranje and Van Huyssteen (2011:6-7) describe post-1994 development planning in South Africa as being characterised by a conflict in intent, action and outcome between service delivery and transformation. 'Servicing' is ensuring a rapid response to a lack of housing and basic services. As such, it has a 'very near-future perspective', concerned with the number of houses completed and services delivered - often in areas where people should not even be living. Oranje and Van Huyssteen (2011:6) argue that the outcome has not necessarily transformed the post-apartheid space economy, but only addressed the symptoms. 'Transformation', on the other hand, is concerned with the restructuring of the entire space economy 'through the pursuit of shared, sustainable, equitable and inclusive growth'. However, much more emphasis has been placed on servicing, which means that many communities may have houses and basic services, but the expansion of the economy into these 'serviced' areas has been minimal and people remain far from social and economic opportunities; for it is often assumed by planners and politicians that it is possible to change the spatial pattern of economic growth and development through state intervention. Municipalities, furthermore, face a number of challenges in overcoming the apartheid spatial legacy: lack of funds; lack of technical, managerial, financial and planning skills and capacity to take up the developmental role; institutional transformation issues because of the amalgamation of municipalities; economic woes inherited from apartheid; huge service delivery backlogs; and intergovernmental misalignment and complexity (Oranje \& Van Huyssteen 2011:8; Van Huyssteen et al. 2010:27). Thus the short-term focus on attaining 'servicing' targets (which are immediate and bottomless) often comes at the expense of long-term and transformative planning (Oranje \& Van Huyssteen 2011) such as planning for disaster resilience.

\section{Translating disaster resilience into spatial planning practice in South Africa}

Before 1994, environmental management, disaster reduction and sustainability, amongst other concerns, received very little attention in South African policy. This changed after 1994 as the process of democratisation resulted in a revised development agenda (Roberts 2008:521). But the simultaneous, parallel development of many policies resulted in duplicated development application processes, competing bureaucracies, interests and agendas, and differences in training, discourse and practice (Todes 2011:123). There was also a growing tension between the need to expedite development to address inequalities, and the need to introduce sustainability concerns such as environmental management and disaster reduction into planning. As described above, development won out as the priority, so that long-term issues were of less immediate concern. There are exceptions, but for the most part this tension has still not been resolved, but has, in many cases, intensified due to the range of immediate and severe development challenges (Roberts 2008:523). For example, the author has found that planning for everyday disaster resilience is not a priority amongst planners in some municipalities in South Africa 
due to the pressure of providing for immediate development needs, so that they do not even deem reducing the risk of natural disasters to be part of the planning process, but rather as part of what the 'environmental people' do (Faling, Tempelhoff \& Van Niekerk 2012).

What follows is a case study of the City of Durban in South Africa - a metropolitan city facing typical development challenges - and how they have started to mainstream climate change adaptation into their everyday planning. This serves as a hypothetical demonstration that the mainstreaming of disaster resilience in spatial planning can be accomplished if approached in such a way that it is seen as part of the immediate development agenda and integrated into existing planning strategies and everyday planning practices.

\section{Case study: Climate change adaptation in Durban}

Durban is a coastal city with the largest port on the east coast of Africa. The eThekwini Municipality manages the 2300 square kilometre municipal area that hosts a population of 3.5 million people and is South Africa's third biggest urban economy (Carmin et al. 2012:20; Roberts 2008:521; SACN 2012:37).

The City of Durban faces typical post-apartheid challenges as described above. It also experiences severe weather events such as flooding, storms, droughts and tornadoes. To this extent, a report commissioned by the Municipality on climate change suggests that over time Durban would experience minimum and maximum temperature increases; and rainfall would become more infrequent, but more severe - causing flooding and high tide levels. The report also indicates that the sea level is rising by $2.7 \mathrm{~cm}$ per decade. These changes in the climate and sea level will affect numerous sectors in the city such as food security, health, infrastructure, water security, biodiversity and the economy, and many people will become more vulnerable to disaster risks (Carmin et al. 2012:18-21; Roberts 2008:528). At that time, few strategies in eThekwini engaged proactively with each other to reduce the risk for disasters due to extreme weather events. Moreover, the disaster management sector was mostly responsive to emergencies, not focusing on proactively planning to minimise exposure and susceptibility, relocating people and infrastructure away from high risk areas, or on developing early warning systems. As severe weather events started to cause more damage to the city during the last decade notably the severe flooding in 2007 and coastal erosion that caused significant damage to the coastline around Durban - the Municipality started to wake up to the consequences of these events, and realised that many of the post-apartheid development gains are already being undermined or lost, and will be exacerbated further by climate change. Climate change adaptation, or resilience-focused interventions, started to achieve prominence in Durban for the potential it offers for 'development-linked co-benefits that are responsive to a context of poverty and underdevelopment' (Carmin et al. 2012; Roberts 2008:532, 2010:398-399).
It still took some time, and trial and error, for Durban to be recognised today as one of the leaders in climate change adaptation. To start with, the Environmental Management Department commissioned the development of an adaptation strategy, published in 2006, which summarised general adaptation actions that could be taken by sector departments. It was an important document to further the debate on climate change in the city, but it did not act as a catalyst for action - in part because it did not specify goals and actions for specific departments, and partly because many departments were dealing with work backlogs and overloads, as well as a lack of funding and capacity (Roberts 2010: 401). In 2008, the Environmental Management Department, whose name changed to the Environmental Planning and Climate Protection Department (EPCPD) - to indicate the priority given to climate change in the city realised that to gain widespread support for an adaptation plan, they had to shift the emphasis from the threats climate change presented to presenting adaptation as a means to realise immediate development priorities. Work was started on individual plans for specific sector departments by embedding adaptation planning into existing business plans and development objectives. These plans formulated measures and protocols to maintain or improve the functioning of municipal systems, services and infrastructure given the projected impacts of climate change. 'Essentially, the goal was to build increased resilience one adaptation intervention at a time' (Roberts 2010:401). Climate change considerations were also factored into the overall long-term plans and budgets of the municipality (Carmin et al. 2012:2123; Roberts 2008:533, 2010:401).

Notwithstanding exogenous factors such as the growing demand from global and local civil society to address climaterelated issues, or international treaties, three endogenous factors seem initially to have driven the adaptation initiatives in Durban. One is the efforts by a champion who pushed the adaptation agenda and creatively navigated the minefield that is local government. Two, the city came under the impression of the gravity of climate change impacts and the danger their residents were in if it became more severe. Three, the municipality realised that climate change adaptation was a means to secure the city's development path whilst simultaneously addressing sustainability and resilience (Carmin et al. 2012:28). eThekwini found ways to link adaptation to existing policies and plans to 'demonstrate that this is not an unfamiliar or inconsequential issue but one that was already part of current citywide priorities and initiatives' (Carmin et al. 2012:29). Adaptation came to be seen as integral to the ongoing work of municipal departments and is starting to influence planning practices in the city.

If the City of Durban managed to integrate climate change consideration into their various sector plans which are starting to have an impact on the way the city is planned, then surely other South African cities can attempt to mainstream disaster resilience (including climate change adaptation) into their spatial planning practices? 


\section{Conclusion}

It is very likely that losses to lives, livelihoods, assets and infrastructure will increase in the future as more people migrate to cities and as the effects of global processes such as climate change increase communities' vulnerability and disaster risk. Many of the implications will be beyond the capacity and experience of local governments to address, wiping out development gain and diverting scarce funds toward disaster relief and reconstruction. Developing countries will suffer most from these impacts, increasing the risk divide within and between nations.

Disaster resilience attempts to reduce these losses by mainstreaming physical, social, economic and environmental measures into planning practices to allow urban systems to accommodate, absorb, adapt to or bounce back from shocks to the urban system. Spatial planning is critical in building this resilience. By managing growth and change in cities, spatial planning can promote liveability, sustainability and inclusion (Todes 2011:128). By mainstreaming disaster resilience (including climate change adaptation) into spatial planning practices, these development endeavours can be protected from future losses.

Post-apartheid spatial planning has had 'far more of a life on paper than in practice' due to various fears and concerns and inabilities concerning implementation (Oranje 2010:66). Planning in South Africa is burdened with addressing housing and service backlogs; fragmented and sprawled spatial patterns and inefficient transportation systems that result in unequal access to urban functions and the economy; challenges of intergovernmental coordination; and so forth. To add another distinct burden - that of building disaster resilient cities - would be met with contempt or despair. The Durban experience shows how planners and officials can be entrepreneurial and innovative in seeking to promote an emerging policy domain. What can be learnt from this ongoing initiative that is slowly starting to influence the way Durban is being planned and managed, is that by presenting disaster resilience as a means to realise a city's immediate development priorities whilst protecting the development gain, it is more likely that resilience would be translated into spatial planning practice in South Africa than if it were presented as a policy paradigm inconsequential from what planners are already doing.

\section{Acknowledgements}

This article was originally written as a paper for the Association of European Schools of Planning (AESOP) 2012 Conference, 11 July 2012 - 15 July 2012, Ankara, Turkey.

\section{Competing interests}

The case study research was funded by UN-Habitat through the Cities and Climate Change Academy initiative.

\section{References}

Biermann, S., 2011, 'Planning support systems in a multi-dualistic spatial planning context', Journal of Urban Technology 18(4), 5-37. http://dx.doi.org/10.1080/1 0630732.2011.648432

Biesbroek, G., Swart, R. \& Van der Knaap, W., 2009, 'The mitigation-adaptation dichotomy and the role of spatial planning', Habitat International 33, 230-237. http://dx.doi.org/10.1016/j.habitatint.2008.10.001

Carmin, J., Anguelovski, I. \& Roberts, D., 2012, 'Urban climate adaptation in the global south: planning in an emerging policy domain', Journal of Planning Education and Research 32(1), 18-32. http://dx.doi.org/10.1177/0739456X11430951

Coaffee, J., 2009, Terrorism, Risk and the Global City, Ashgate Publishing Limited, Surrey.

Coaffee, J., Wood, D. \& Rogers, P., 2009, The Everyday Resilience of the City: How Cities Respond to Terrorism and Disaster, Palgrave Macmillan, Hampshire.

Collins, A., 2009, Disaster and Development, Routledge, Oxon.

Ernstson, H., 2008, 'In Rhizomia - Actors, Networks and Resilience in Urban Landscapes', PhD thesis in Natural Resource Management, Department of Systems Ecology, Stockholm University, Stockholm.

Faling, W., 2012, 'A spatial planning perspective on climate change, asset adaptation and food security: The case of two South African cities', in B. Frayne, C. Moser \& G. Ziervogel (eds.), Climate Change, Assets and Food Security in Southern Africa, pp. Ziervogel (eds.), Climate Change, Assets and Food Security in Southern Africa, pp.
163-185, Earthscan, Oxon. http://dx.doi.org/10.1080/0376835X.2012.675695

Faling, W., Tempelhoff, J. \& Van Niekerk, D., 2012, 'Rhetoric or action: Are South African municipalities planning for climate change?', Development Southern African municipalities
Africa 29(2), 241-257.

Freeman, P.K., Marin, L.A., Mechler, R., Warner, K. \& Hausmann, P., 2002, June, 'Catastrophes and development: Integrating natural catastrophes into development planning', Disaster Risk Management Working Paper Series (4), The development planning', Disaster
World Bank, Washington D.C.

Hamin, E. \& Gurran, N., 2009, 'Urban form and climate change: Balancing adaptation and mitigation in the U.S. and Australia', Habitat International 33, 238-245. http://dx.doi.org/10.1016/j.habitatint.2008.10.005

ICLEI, 2010, Resilient Communities and Cities Initiative, International Council for Local Environmental Initiatives, Toronto.

IFRC, 2010, World Disaster Report 2010: Focus on Urban Risk, International Federation of Red Cross and Red Crescent Societies, Geneva.

IPCC, 2007, Climate Change 2007: Synthesis Report. Contribution of Working Groups I, II and III to the Fourth Assessment Report of the Intergovernmental Panel on Climate Change, (core writing team R.K. Pachauri \& A. Reisinger (eds.)), Intergovernmental Panel for Climate Change, Geneva.

Laukkonen, J., Blanco, P., Lenhart, J., Keiner, M., Cavric, B. \& Kinuthia-Njenga, C., 2009, 'Combining climate change adaptation and mitigation measures at the local level', Habitat International 33, 287-292. http://dx.doi.org/10.1016/j. habitatint.2008.10.003

Oranje, M., 2010, 'Post-apartheid national spatial development planning in South Africa - A brief history', European Spatial Research and Policy 17(2), 55-70. http:// dx.doi.org/10.2478/s10105-010-0010-8

Oranje, M. \& Van Huyssteen, E., 2011, 'Nestling national "transformation" imperatives in local "servicing" space: Critical reflections on an intergovernmental planning and implementation project', Town and Regional Planning 58, 6-16.

Parnell, S., Simon, D. \& Vogel, C., 2007, 'Global environmental change: conceptualising the growing challenge for cities in poor countries', Area 39(2), 357-369. http:// dx.doi.org/10.1111/j.1475-4762.2007.00760.x

Pelling, M., 2003, The Vulnerability of Cities: Natural Disasters and Social Resilience, Earthscan Publications Ltd, London.

Pelling, M., 2011, Adaptation to Climate Change: From Resilience to Transformation, Routledge, Oxon.

Pelling, M. \& Wisner, B., 2009, Disaster Risk Reduction: Cases from Urban Africa, Earthscan, London.

Puppim de Oliveira, J., 2009, 'The implementation of climate change related policies at the sub-national level: An analysis of three countries', Habitat International 33 253-259. http://dx.doi.org/10.1016/j.habitatint.2008.10.006

Roberts, D., 2008, 'Thinking globally, acting locally - institutionalizing climate change at the local government level in Durban, South Africa', Environment \& Urbanization 20(2), 521-537. http://dx.doi.org/10.1177/0956247808096126

Roberts, D., 2010, 'Prioritizing climate change adaptation and local level resilience in Durban, South Africa', Environment \& Urbanization 22(2), 397-413. http://dx.doi. org/10.1177/0956247810379948

SACN, 2012, Secondary Cities in South Africa: The start of a conversation, South African Cities Network.

The Presidency, 2009, Medium Term Strategic Framework: 2009-2014, Republic of South Africa, Government Printer, Pretoria.

Todes, A., 2011, 'Reinventing planning: Critical reflections', Urban Forum 22, 115-133.

UN-Habitat, 2010, Cities and Climate Change: Initial Lessons from UN-Habitat, Sustainable Urban Development Network (SUD-Net), United Nations Human Settlement Programme (UN-Habitat), Nairobi. 
UNISDR, 2010a, Local Governments and Disaster Risk Reduction: Good Practices and Lessons Learnt, United Nations International Strategy for Disaster Reduction, Geneva.

UNISDR, 2010b, The International Strategy for Disaster Reduction: Connect and Convince, viewed June 22, 2011, from http://www.unisdr.org/files/14044 ISDRbrochure2010.pdf

Vale, L. \& Campanella, T., 2005a, 'Introduction: The cities rise again', in L. Vale \& T. Campanella (eds.), The Resilient City: How Modern Cities Recover from Disaster, pp. 3-26, Oxford University Press, New York.

Vale, L. \& Campanella, T., 2005b, 'Conclusion: Axioms of resilience', in L. Vale \& T. Campanella (eds.), The Resilient City: How Modern Cities Recover from Disaster, pp. 335-356, Oxford University Press, New York.

Van Huyssteen, E., Meiklejohn, C., Coetzee, M., Goss, H. \& Oranje, M., 2010, 'An overview of South Africa's metropolitan areas - dualistic, dynamic and unde threat', European Spatial Research and Policy 17(2), 23-40. http://dx.doi. org/10.2478/s10105-010-0008-2
Watson, V., 2005, 'The usefulness of normative planning theories in Sub-Saharan Africa', in B. Stiftel \& V. Watson (eds.), Dialogues in urban and regional planning, pp. 273-298, Routledge, Oxon. http://dx.doi.org/10.4324/9780203314623_ chapter_11

Wisner, B. \& Pelling, M., 2009, 'Urbanization and disaster risk reduction in Africa', in M. Pelling \& B. Wisner (eds.), Disaster Risk Reduction: Cases from Urban Africa, pp. 3-16, Earthscan, London.

World Bank, 2008, Climate Resilient Cities: A Primer on Reducing Vulnerabilities to Climate Change Impacts and Strengthening Disaster Risk Management in East Asian Cities, The International Bank for Reconstruction and Development, The World Bank, Washington D.C.

World Bank \& United Nations, 2010, Natural Hazards, UnNatural Disasters: The Economic of Effective Prevention, The International Bank for Reconstruction and Development/The World Bank, Washington D.C.

World Bank Institute, 2012, April 30, Africa's urban future: building globally competitive cities, viewed 02 May 2012, from http://wbi.worldbank.org/wbi/ stories/africa\%E2\%80\%99s-urban-future-building-globally-competitive-cities 